\title{
PREFERENSI GAYA BELAJAR MAHASISWA AKUNTANSI
}

\author{
Sri Pujiningsih \\ Sulastri \\ Fakultas Ekonomi Universitas Negeri Malang \\ e-mail: Pujiningsihsri23@yahoo.com
}

\begin{abstract}
This study aims to find the differences between learning style preference in accounting students. Results of this research useful to determine teaching strategies, so it can support improvement of student learning. Based on the analysis of test results using ANOVA can be concluded that there is no difference in student learning styles accounting students. Learning style preferences of three groups of students is the same that is more like the learning style dependent.
\end{abstract}

Keywords: Gaya Belajar, Strategi Mengajar.

Berdasarkan hasil penelitian mengenai preferensi gaya belajar dosen Akuntansi Fakultas Ekonomi Universitas Negeri Malang (FE-UM) dengan pendekatan yang dikembangkan Kolb, dosen akuntansi sebagian besar memiliki gaya belajar accomodator. Gaya belajar ini merupakan perpaduan gaya belajar antara perceiving information secara concentrate experience (CE) dan processing information secara Active Experiments (AE). Dengan kata lain gaya belajar ini, menunjukkan kecenderungan seseorang dalam belajarnya lebih menyukai pengalaman dan aktif mempraktikkannya (Pujiningsih, 2006). Hasil penelitian ini berbeda dengan hasil penelitian Adel at.al. (2003), bahwa berdasarkan hasil penelitian tersebut menunjukkan, sebagian besar mahasiswa akuntansi memiliki gaya belajar converger, yakni gaya belajar h dengan cara memikirkannya (Abstract Conceptualization/AC) serta memproses informasi yang diperoleh dengan cara mempraktikannya (active experimentation/AE)

Berdasarkan temuan penelitian tersebut, penelitian ini bermaksud untuk mengetahui preferensi gaya belajar mahasiswa akuntansi FE-UM yang paling dominan di antara mahasiswa jurusan Akuntansi di masing-masing program studi. Dengan diketahuinya preferensi gaya belajar mahasiswa akuntansi FE-UM pada masing-masing prodi dapat dijadikan dasar untuk menentukan strategi pembelajaran. Mengingat, terdapat tiga program studi (Prodi) pada jurusan 
Akuntansi FE-UM, yaitu Prodi Pendidikan Akuntansi dengan jenjang strata satu (S1) yang akan menghasilkan guru bidang akuntansi, Prodi S1 Akuntansi (Non Kependidikan ) yang akan menghasilkan Sarjana Ekonomi bidang akuntansi, serta Prodi Diploma Tiga Akuntansi (D3) yang menghasilkan Ahli Madya di bidang akuntansi. Ketiga Prodi tersebut menghasilkan lulusan dengan karakteristik yang berbeda, meskipun masih dalam satu disiplin ilmu akuntansi. Perbedaan tersebut tentunya juga memerlukan strategi pembelajaran yang berbeda.

Penelitian ini berbeda dengan penelitian Adel (2003) yang menggunakan Prodi lain selain akuntansi untuk mengidentifikasi preferensi gaya belajar mahasiswa dengan pendekatan Kolb. Berdasarkan keterbatasan penelitian Adel tersebut tersebut dimungkinkan akan menghasilkan hasil gaya belajar yang berbeda apabila diterapkan pada lingkungan yang berbeda. Pendekatan Canfield disarankan cocok untuk penelitian pendidikan akuntansi (Francis et.al, 1995), penelitian ini dikembangkan dengan mengadaptasi instrument yang dikembangkan dalam Canfield's LSI. Meskipun pendekatan tersebut disarankan untuk pendidikan akuntansi, Barbara et al. menemukan bukti bahwa Canfield's LSI hanya sedikit mendukung dalam penelitian akuntansi. Penelitian ini menambahkan pendekatan lain dalam melihat preferensi gaya belajar seseorang dari sisi kepribadiannya, yakni dengan pendekatan MBTI yang dikembangkan oleh Jung.

\section{Kajian Pustaka}

Learning Style (Gaya Belajar)

Terdapat beberapa teori dan model tentang gaya pembelajaran atau learning style dan faktor-faktor yang mempengaruhi gaya belajar seseorang. Secara umum model gaya pembelajaran dapat diklasifikasikan dalam tiga ruang lingkup, yaitu information processing, environment, dan personality (Hickoc, 1995). Beberapa instrument untuk menilai gaya belajar seseorang telah banyak dikembangkan oleh beberapa ahli antara lain dikembangkan oleh Kolb $(1976,1984)$ yang dikenal dengan Learning Style Inventory (LSI) atau Kolb'LSI. Model yang dikembangkan oleh Carl Jung yang kemudian dikenal dengan nama Myers Briggs Type Indicator (MBTI). Model Multiple Intelegence yang dikembangkan oleh Howard Gardner (1993). Model lain yang dikembangkan oleh Canfield disebut dengan Learning Style Inventory (Canfaild'LSI). Berikut akan dijelaskan secara ringkas dari masing-masing pendekatan gaya belajar tersebut. 


\section{Kolb's Laerning Style Inventory}

Menurut Kolb pembelajaran memiliki dua dimensi perceiving informasi dan processing information. Dalam model Kolb ini, lebih memfokuskan pada bagaimana pembelajar paling banyak mendapatkan informasi dan bagaimana mereka lebih menyukai cara untuk memroses informasi tersebut. Pertama, Perceiving information adalah pembelajar dalam mendapatkan informasi dengan concentrate experience (pembelajaran dari feeling, personal experience, dan involvement) atau abstract conceptualization (learning by thinking). Dalam proses pembelajaran, pembelajar berpindah dari tingkatan yang berbeda dari yang spesifik sampai pada yang umum. Seseorang paling banyak mendapatkan informasi dari pengalaman yang dialami sehari-hari. Dalam hal ini biasanya pembelajar lebih banyak menggunakan feeling mereka. Di lain pihak pembelajar yang cenderung menyukai gaya abstrak lebih banyak menggunakan logika berfikir kemudian menganalisis informasi yang mereka dapatkan. Meskipun kemungkinan setiap individu menggunakan kedua-duanya dalam menerima informasi, dalam waktu tertentu mereka cenderung menyukai salah satu concentrate experieance atau abstract conceptualization.

Dimensi kedua dalam pembelajaran adalah memroses informasi (processing information) yang sudah didapatkan. Pemrosesan informasi terjadi dengan melalui reflective observation (melihat/mendengar) atau active experiment (melakukan). Pada pemrosesan informasi ini pembelajar berpindah dari tingkatan yang berbeda, mulai dari observer atau pengamat sampai menjadi pelaku atau actor. Pembelajar yang reflective memroses informasi dengan cara mendengar dan melihat sesuatu. Di sisi lain pembelajar yang aktif akan memroses informasi dengan cara langsung memraktikkannya. Meskipun setiap individu kemungkinan juga menggunakan kedua-duanya dalam memroses informasi, dalam waktu terentu mereka lebih menyukai salah satu, observation atau active experiment.

Untuk mengidentifikasi prefensi seseorang dalam menerima dan memroses informasi (Kolb, 1984) telah mengembangkan instrumen yang disebut learning style Inventory (LSI). Instrumen tersebut terdiri dari 12 pertanyaan yang meminta responden untuk mengurutkan pernyataan tentang perceiving dan processing informasi, mulai dari yang paling disukai sampai yang paling tidak disukai.

Selanjutnya berdasarkan penelitian Kolb terdapat empat jenis gaya belajar, yakni accomodator, diverger, assimilator dan converger. Gaya belajar accomodator adalah 
gaya belajar seseorang yang lebih menyukai pengalaman (concentrate experience) dan aktif bereksperimen (active experimentation). Dengan kata lain, seseorang yang lebih menyukai mendapatkan informasi dari feeling dan memrosesnya dengan cara memraktikkan atau melakukannya. Kedua, gaya belajar diverger adalah gaya belajar seseorang yang lebih menyukai pengalaman (concentrate experiencing) dan mengamati (reflective observation). Dengan kata lain, pembelajar diverger adalah seseorang yang lebih menyukai memperoleh informasi dengan feeling dan memrosesnya dengan cara melihat dan mendengar. Ketiga, gaya belajar converger adalah gaya belajar seseorang yang lebih menyukai sesuatu yang abstrak (abstract conceptualization) dan aktif bereksperimen (active experimentation). Dengan kata lain, gaya converger ini adalah gaya pembelajar yang dalam memperoleh informasi dengan cara memikirkan (tinking) dan kemudian melakukannya (doing). Dan keempat, gaya belajar assimilator adalah gaya belajar seseorang yang lebih menyukai pada sesuatu yang abstrak (abstract conceptualization) dan mengamati (reflective observation). Dengan kata lain gaya assimilator adalah gaya belajar seseorang yang lebih menyukai belajar dengan cara berfikir serta melihat atau mendengar. Kelemahan dari model Kolb adalah gaya belajar yang dinilai sendiri oleh individu yang bersangkutan, tidak dapat menunjukkan atau mengukur actual behaviour atau perilaku yang sebenarnya (Adel et al, 2003). Kelemahan lain adalah bahwa Kolb's LSI kurang atau miskin dalam menilai aspek psikomotorik (Stont, Rable, 1994).

\section{Myers Briggs Type Indicator (MBTI)}

Awal tahun 1900 -an, Carl Jung mencoba untuk mengidentifikasi perbedaan pola kepribadian yang kemudian dikenal dengan Myers Briggs Type Indicator (MBTI). MBTI adalah instrument yang digunakan untuk melihat perbedaan kepribadian setiap individu. Pendekatan ini berkaitan dalam gaya belajar sesorang yang menyangkut pada kepribadiannya. Dalam MBTI preferensi gaya belajar seseorang dibedakan menjadi empat dimensi. Pertama, Extroversion Vs Introversion. Introvert menemukan kekuatan dalam inner world dari ide konsep dan abstraksi. Dalam memahami fenomena tipe pembelajar ini cenderung lebih banyak berfikir dibandingkan berbicara. Introvert leaner dalam mengembangkan kerangka kerja dengan cara menyatukan dan menghubungkan informasi yang mereka pelajari. Pengetahuan yang diperolehnya kemudian saling dihubungkan untuk melihat sesuatu tersebut secara menyeluruh. Kemudian extrovert learner menemukan 
kekuatan pada benda dan orang. Mereka lebih suka berinteraksi dengan orang lain. Mereka lebih suka berbicara dibandingkan mendengarkan. Mereka dapat belajar dari pengajar yang lain. Secara umum mereka tidak dapat memahami pelajaran sampai mereka dapat menjelaskan pada diri mereka sendiri atau pada orang lain (bekerja kelompok). Problem based Learning dan collaborative learning cocok untuk model pembelajaran.

Kedua, Sensing Vs Intuition. Sensing learner adalah pembelajar yang lebih menyukai belajar dengan menggunakan kelima panca indra mereka. Mereka lebih menyukai sesuatu dengan rinci dan menginginkan fakta. Mereka lebih menyukai segala sesuatu ditata dengan teratur, pengajaran dilakukan secara terstruktur tahap demi tahap. Berbeda dengan Intuitive learner, mereka adalah pembelajar yang lebih menyukai berimajinasi dan berinovasi. Ketiga, Thinking Vs Feeling. Thinking learner adalah pembelajar yang dalam memutuskan sesuatu berdasarkan pada analisis, logika dan prinsip. Dengan kata lain mereka dalam melihat sesuatu lebih kritis dan obyektif. Berbeda dengan feeling learner mereka lebih menggunakan pertimbangan nilai-nilai kemanusiaan (human values) dalam pengambilan keputusan. Mereka cenderung menjaga keharmonisan hubungan sosial dalam suatu kelompok. Mereka lebih menyukai bekerja dalam kelompok kecil.

Dan keempat, Judging Vs Perceptive. Judging learner adalah pembelajar yang cenderung melakukan semua tugas lebih cepat dari batas waktu yang ditentukan. Mereka menyukai tips atau panduan bagaimana cara mengerjakan sesuatu dengan cepat. Berbeda dengan perceptive learner, mereka cenderung menunda tugas sampai menjelang batas akhir waktu yang ditentukan.

\section{Canfaild's Learning Style Inventory}

Canfield Learning Inventory adalah instrumen yang digunakan untuk mengidentifikasi gaya belajar individu yang cakupannya dipandang lebih luas cakupannya dibanding Kolb'LSI. Menurut Canfield (1998) gaya belajar individu yang dibedakan dalam beberapa jenis yaitu social, independent, applied dan conceptual. Pembelajar tipe sosial, adalah mereka yang lebih suka belajar secara kelompok. Pembelajar yang independet adalah mereka yang lebih menyukai belajar secara mandiri. Pembelajar applied lebih menyukai belajar dengan berpraktik langsung. Adapun conceptual leraner adalah pembelajar yang lebih menyukai belajar secara konseptual. 
Canfield' LSI membagi preferensi gaya pembelajaran seseorang dapat dilihat dari condition for laerning, area of interest, dan mode of learning. Conditions for Learning merupakan aspek untuk melihat dinamika preferensi individu dalam lingkungan pembelajaran. Yang termasuk dalam lingkup ini adalah peer, organization, goal setting, competition, instructure, detail, independent dan outhority. Selanjutnya Area of Interest. digunakan untuk melihat ketertarikan individu pada obyek belajar. Yang termasuk dalam lingkup ini adalah numeric, qualitative, inanimate, dan people. Dan Mode of Learning, yang digunakan untuk melihat basic sensory dan cognitive modality dari pembelajar dalam mendapatkan informasi baru. Yang termasuk dalam hal ini adalah listening, reading, iconic (visual) dan direct experiment.

Preferensi gaya belajar adalah sesuatu yang kompleks dan banyak bentuk (Claxton, murrel,1987). Berdasarkan hal ini Canfield'LSI merupakan instrumen yang memiliki cakupan lebih luas dibanding Kolb's LSI, dalam menilai preferensi gaya belajar seseorang. Kelebihan dari Canfiled ini adalah bahwa individu akan memiliki preferensi gaya belajar yang merupakan kombinasi yang seimbang diantara condition of learning, area of interest dan mode of laerning.

Francis et. Al (1995) menyarankan bahwa Canfiled LSI cocok digunakan dalam penelitian pendidikan akuntansi. Mesekipun Barbara et. al. (2001) menyatakan bahwa Canfield LSI hanya sedikit mendukung pada penelitian akuntansi. Hal ini dikarenakan keterbatasan teoritis yang mendukung dan kurang adanya dasar kebenaran (justification) secara empiris. Berdasarkan hasil penelitian mengenai preferensi gaya belajar dosen Akuntansi FE-UM dengan pendekatan yang dikembangkan Kolb, dosen akuntansi sebagian besar memiliki gaya belajar accomodator, yakni sebanyak $0,38 \%$ atau 8 orang. Gaya belajar ini merupakan perpaduan gaya belajar antara perceiving information secara concentrate experience (CE) dan processing information secara Active Experiments (AE). Dengan kata lain gaya belajar ini, menunjukkan kecenderungan seseorang dalam belajarnya lebih menyukai pengalaman dan aktif mempraktikkannya (Pujiningsih, 2006). Hasil penelitian ini berbeda dengan hasil penelitian Adel at.al. (2003), bahwa berdasarkan hasil penelitian tersebut menunjukkan, sebagian besar mahasiswa akuntansi memiliki gaya belajar converger, yakni gaya belajar dimana cara memperoleh dengan cara memikirkannya (Abstract Conceptualization/AC) serta memproses informasi yang diperoleh dengan cara mempraktikannya (active experimentation/AE) 
Penelitian Adel at.al. (2003) menunjukkan hasil bahwa mahasiswa akuntansi, dalam hal ini mahasiswa Non-Kependidikan, lebih menyukai gaya belajar converger. Motivasi dari penelitian ini adalah untuk mengetahui apakah mahasiswa S1 Akuntansi non kependidikan juga akan memiliki gaya yang sama yakni converger. Mengingat, berdasarkan hasil penelitian mengenai gaya belajar dosen Akuntansi FEUM adalah bergaya accomodator. Selain itu, penelitian ini juga termotivasi untuk melihat perbedaan gaya belajar mahasiswa S1 Akuntansi, S1 Pendidikan Akuntansi dan D3 Akuntansi. Hal ini bertujuan untuk menentukan strategi pembelajaran.

\section{Metode Penelitian}

Populasi dalam penelitian ini adalah para mahasiswa Prodi D3 Akuntansi, Prodi S1 Pendidikan Akuntansi, dan Prodi S1 Akuntansi Non-Kependidikan FE-UM yang terdaftar pada semester gasal tahun 2007. Pengambilan sampel dilakukan secara proporsional pada masing-masing Prodi, dengan jumlah keseluruhan sebesar 150 mahasiswa.

Jenis data yang digunakan dalam penelitian ini adalah data primer. Data diperoleh dengan instrument berupa angket yang telah diisi oleh responden. Angket yang digunakan dalam penelitian dikembangkan oleh peneliti dengan mengadaptasi pendekatan Kolb'S LSI Canfield's LSI dan MBTI Model. Sebelum digunakan dalam pengambilan data, instrumen tersebut terlebih dahulu akan diujicobakan kepada mahasiswa. Dalam pengembangan kuesioner digunakan skala likert dengan menggunakan 4 skala. Masing-masing butir peryataan diberi skor 4 yang berarti sangat setuju, 3 berarti setuju, 2 berarti tidak setuju dan 1 berarti setuju. Dalam penelitian ini dikembangkan sebanyak 36 butir peryataan.

Kemudian untuk menjawab permasalahan yang pertama teknik analisis data yang digunakan yaitu teknik ANOVA. Teknik ini digunakan untuk mengetahui perbedaan masing-masing gaya belajar di masing-masing Prodi akuntansi. Sedangkan untuk menjawab permasalahan yang kedua, yakni mengenai preferensi gaya belajar pada masing-masing Prodi. Alat analisis yang digunakan adalah dengan menggunakan $z$ scores atau standart score. Teknik ini digunakan untuk mengetahui nilai $\mathrm{z}$ pada masing-masing butir pernyataan. Nilai yang tertinggi pada sebuah butir peryataan menunjukkan preferensi responden dalam gaya belajarnya. 


\section{Perbedaan Gaya Belajar Mahasiswa S1 Non Pendidikan Akuntansi, D3 Akuntansi dan S1 Pendidikan Akuntansi}

Berdasarkan pada hasil pengolahan data dengan menggunakan teknik ANOVA,didapatkan hasil bahwa tidak terdapat perbedaan gaya belajar di antara mahasiswa program studi D3 akuntansi, SI Pendidikan akuntansi maupun S1 Non Pendidikan Akuntansi. Hal ini berdasarkan pada hasil nilai probabilitas yang lebih besar dari 0,05 yaitu sebesar 0.195. Berdasarkan hasil tersebut dapat disimpulkan bahwa baik mahasiswa S1 Non Pendidikan Akuntansi, D3 Akuntansi dan S1 Pendidikan Akuntansi tidak memiliki perbedaan dalam gaya belajar. Dengan demikian dalam kaitannya dengan strategi penyampaian materi perkuliahan oleh dosen untuk ketiga program studi tersebut dapat menggunakan strategi yang sama. Hal ini merujuk pada penelitian lain yang menunjukkan mahasiswa dengan gaya belajar yang sama dengan dosen akan memiliki kinerja yang lebih baik atau lebih tinggi kepuasannya selama mengikuti kuliah (Geiger \& Boyle,1992).

Hasil uji Z score untuk mahasiswa Prodi S1 Pendidikan Akuntansi, telah diketahui bahwa nilai tertinggi terletak pada butir pernyataan yang ke tiga dengan nilai $Z=1,99$, yang berarti bahwa mahasiswa S1 Pendidikan Akuntansi lebih menyukai dosen yang dalam menyajikan materi menjelaskan secara detail atau terperinci. Berdasarkan model gaya belajar MBTI, mahasiswa S1 pendidikan termasuk Sensing learner adalah pembelajar yang lebih menyukai belajar dengan menggunakan kelima panca indra mereka. Mereka lebih menyukai sesuatu dengan rinci dan menginginkan fakta. Mereka lebih menyukai segala sesuatu ditata dengan teratur, pengajaran dilakukan secara terstruktur setahap demi setahap. Sedangkan apabila dipandang dari model gaya belajar Canfield, gaya semacam ini termasuk dalam Conditions for Learning (detail). Aspek ini untuk melihat dinamika preferensi individu dalam lingkungan pembelajaran, untuk temuan penelitian pada mahasiswa Prodi S1 Akuntansi termasuk dalam detail. Dalam tipe ini individu cenderung menyukai penjelasan yang terperinci dalam proses pembelajaran.

Berdasarkan hasil pengujian data dengan $\mathrm{Z}$ score, bahwa nilai terendah untuk mahasiswa Prodi S1 Pendidikan Akuntansi terletak pada butir ke-12 dengan nilai $Z=-1,9$ yang menyatakan bahwa mahasiswa lebih suka mengumpulkan tugas menjelang batas waktu yang ditentukan. Hal ini dapat disimpulkan bahwa hanya sebagian kecil saja mahasiswa yang memiliki gaya belajar perceptive, seperti dalam model MBTI, yakni gaya individu yang lebih suka mengerjakan atau 
mengumpulkan tugas menjelang batas waktu yang ditentukan. Dengan kata lain mahasiswa Prodi S1 Pendidikan Akuntansi tidak suka mengumpulkan dan mengerjakan tugas menjelang batas waktu yang ditentukan.

Urutan kedua terletak pada butir peryataan nomor 25 , dengan nilai $Z=1,87$ yang menyatakan bahwa mahasiswa lebih mudah memahami materi apabila dosen memberikan contoh fakta di lapangan. Preferensi gaya belajar ini termasuk direct experiment dalam mode of learning dalam canfaild model. Dalam MBTI model termasuk Extrovert learner, yakni gaya individu dalam menemukan kekuatan pada benda dan orang. Mereka lebih suka berinteraksi dengan orang lain. Mereka lebih suka berbicara dibandingkan mendengarkan. Mereka dapat belajar dari pengajar yang lain. Secara umum mereka tidak dapat memahami pelajaran sampai mereka dapat menjelaskan pada diri mereka sendiri atau pada orang lain (bekerja kelompok). Problem based Learning dan collaborative learning cocok untuk model pembelajaran. Sedangkan berdasarkan Kolb model, gaya ini termasuk gaya belajar accomodator yakni gaya belajar seseorang yang lebih menyukai pengalaman (concentrate experience) dan aktif ber-eksperimen (active experimentation). Dengan kata lain, seseorang yang lebih menyukai mendapatkan informasi dari feeling dan memrosesnya dengan cara mempraktikkan atau melakukannya.

Untuk mengetahui preferensi gaya belajar mahasiswa Prodi S1 Non Pendidikan Akuntansi diperoleh hasil bahwa nilai $\mathrm{Z}=2,24$ yang terletak pada butir pernyataan yang ke tiga yakni, mahasiswa Prodi S1 Akuntansi lebih menyukai dosen yang dalam menyampaikan materi secara rinci dan jelas. Temuan penelitian ini sama dengan hasil temuan penelitian pada mahasiswa Prodi S1 Pendidikan Akuntansi. Mahasiswa prodi S1 Non Pendidikan Akuntansi FE-UM dapat disimpulkan memiliki gaya belajar sensing, seperti dalam model MBTI dan detail seperti dalam model Canfaild

Urutan kedua nilai $Z$ terletak pada butir $27, Z=1,56$, yang menyatakan bahwa mahasiswa Prodi S1 Non Pendidikan Akuntansi lebih menyukai gambar yang disajikan pada saat membaca buku, atau dalam Canfaild model disebut gaya visual. Sedangkan untuk Kolb model termasuk gaya belajar diverger yakni gaya belajar seseorang yang lebih menyukai pengalaman (concentrate experiencing) dan mengamati (reflective observation). Dengan kata lain, pembelajar diverger adalah seseorang yang lebih menyukai memperoleh informasi dengan feeling dan memrosesnya dengan cara melihat dan mendengar. Sedangkan z skor terendah 
pada mahasiswa S1 Akuntansi adalah $Z=-2,33$ yang terletak pada butir pernyataan no 12 yang berarati bahwa hanya sedikit mahasiswa yang menyukai mengerjakan atau mengumpulkan tugas menjelang batas waktu yang ditentukan. Dengan kata lain mahasiswa Prodi S1 Akuntansi tidak suka mengumpulkan dan mengerjakan tugas menjelang batas waktu yang ditentukan. Gaya seperti ini dapat dikelompokkan dalam gaya perceptive, seperti dalam model MBTI.

Kemudian dengan menggunakan $\mathrm{Z}$ score untuk mengetahui preferensi gaya belajar mahasiswa diperoleh nilai $Z=2,19$ yang terletak pada butir 3 yang menyatakan bahwa mahasiswa Prodi D3 Akuntansi lebih menyukai dosen yang dalam menyampaikan materi dilakukan secara detail dan terperinci. Temuan penelitian ini sama dengan temuan penelitian pada mahasiswa Prodi S1 Pendidikan Akuntansi dan S1 Non Pendidikan Akuntansi. Dengan demikian dapat disimpulkan bahwa mahasiswa di ketiga Prodi memiliki preferensi gaya belajar yang sama yakni detail seperti dalam Canfaild model serta sensing dalam MBTI model.

Skor urutan kedua berdasarkan hasil uji $Z$, dengan $Z=1,88$ terletak pada butir pernyataan nomor 16 yang menyatakan bahwa mahasiswa selalu berusaha mendapatkan nilai yang terbaik di kelas. Gaya ini dalam canfaild model termasuk dalam gaya competition untuk condition for learning. Temuan ini berbeda dengan preferensi kedua mahasiswa prodi S1 Non Pendidikan Akuntansi yang bergaya visual, dan juga berbeda dengan gaya mahasiswa prodi S1 Pendidikan Akuntansi yang direct experiment, extrovert dan accomodator (gaya individu dalam belajar lebih menyukai hal yang praktis).

Sedangkan untuk nilai $Z$ terendah diperoleh $Z=-1,81$ yang terletak pada butir pernyataan no 28, yang menyatakan mahasiswa menyukai materi perkuliahan bersifat teoritis. Hal ini dapat disimpulkan bahwa sebagian kecil mahasiswa yang menyukai materi kuliah yang bersifat teoritis. Dengan kata lain, mahasiswa Prodi D3 Akuntansi sebagian besar tidak menyukai mata kuliah teoritis, dalam Canfaild Model disebut gaya conceptual. Dalam MBTI model termasuk dalam tipe Introvert, yakni gaya individu dalam menemukan kekuatan dalam inner world dari ide konsep dan abstraksi. Dalam memahami fenomena tipe pembelajar ini cenderung lebih banyak berfikir dibandingkan berbicara. Sedangkan dalam gaya Kolb termasuk gaya belajar assimilator yakni gaya belajar seseorang yang lebih menyukai pada sesuatu yang abstrak (abstract conceptualization) dan mengamati (reflective observation). 
Dengan kata lain gaya assimilator adalah gaya belajar seseorang yang lebih menyukai belajar dengan cara berfikir serta melihat atau mendengar.

\section{Gaya Belajar dan Strategi Belajar}

Berdasarkan pada hasil pembahasan penelitian di atas, dapat disumpulkan bahwa tidak terdapat perbedaan gaya belajar mahasiswa Prodi S1 Pendidikan Akuntansi, S1 Non Pendidikan Akuntansi dan D3 Akuntansi. Mahasiswa di ketiga prodi memiliki preferensi gaya belajar yang sama yakni mereka lebih menyukai dosen yang dalam menyampaikan materi perkuliahan secara detail atau terperinci. Dengan demikian berdasarkan hasil penelitian ini dapat disimpulkan, bahwa cara penyampaian materi yang paling efektif oleh dosen adalah dengan menyajikan materi perkuliahan secara terperinci. Strategi ini disesuaikan dengan gaya belajar mereka, sehingga proses pembelajaran dapat berjalan dengan efektif. Namun demikian strategi ini cenderung membentuk perilaku mahasiswa yang dependent, atau tidak mandiri dalam belajar. Untuk membentuk perilaku yang lebih independen mungkin perlu dipertimbangkan strategi penyampaian materi yang lebih kreatif.

Dengan memperhatikan preferensi kedua untuk masing-masing program studi dapat dilakukan strategi pembelajaran di ketiga Prodi adalah sebagai berikut. Strategi pengajaran untuk mahasiswa S1 Pendidikan Akuntansi dapat dilakukan strategi penyampaian materi pembelajaran dengan banyak memberikan contoh ataupun mahasiswa langsung mempraktikkannya, karena mahasiswa bergaya accomodator yang lebih menyukai praktik. Strategi penyampaian materi di kelas, untuk mahasiswa S1 Non Pendidikan Akuntansi dapat dilakukan dengan penggunaan multimedia berbasis kompuer yang diproyeksikan dengan LCD, karena mahasiswa bergaya visual, mereka lebih menikmati sajian materi dengan cara memperhatikan bagan dan gambar, serta visualisasi lain. Strategi penyampaian materi untuk mahasiswa prodi D3 Akuntansi, dapat dilakukan dengan menciptakan suasana kelas yang kompetitif, misalkan pemberian insentif nilai pada mahasiswa yang aktif, yang paling cepat mengerjakan soal dan lain sebagainya, karena mereka bergaya competition. 


\section{Kesimpulan dan Saran}

Kesimpulan

Dari pembahasan hasil penelitian yang telah dikemukakan tersebut dapat disimpulkan bahwa; Pertama, tidak terdapat perbedaan gaya belajar mahasiswa Prodi S1 Non Pendidikan akuntansi, D3 akuntansi maupun S1 Pendidikan Akuntansi. Kedua, berdasarkan hasil analisis dengan menggunakan z score, diperoleh hasil bahwa preferensi gaya belajar mahasiswa berada pada butir pernyataan yang ketiga yang menyatakan bahwa mahasiswa lebih suka dosen yang menjelaskan materi secara rinci atau bergaya dependent. Mahasiwa S1 Pendidikan Akuntansi dan S 1 Non Pendidikan Akuntansi hanya sedikit yang memiliki gaya perceptive. Sedangkan untuk mahasiswa D3 akuntansi, mereka hanya sedikit yang menyukai mata kuliah yang bersifat teoritis atau bergaya assimilator.

\section{Saran}

Berdasarkan hasil penelitian dapat diajukan rekomendasi kepada dosen akuntansi perlu mempertimbangkan gaya belajar mahasiswa yang sebagian bergaya dependent. Dengan demikian strategi penyampaian materi kuliah yang dilakukan oleh dosen adalah dengan menjelaskan materi secara lebih rinci. Namun demikian hal ini memiliki kelemahan yaitu mahasiswa akan menjadi tidak mandiri, di lain pihak pendidikan saat ini lebih menekankan pada model pembelajaran konstruktivisme yang menuntut kemandirian mahasiswa dalam menemukan pengetahuan. 


\section{DAFTAR PUSTAKA}

Adel et.al. 2003. An Investigation into preferred Learnig Styles of accounting, Management, Marketing, and General Business Majors, Teaching \& Learning, Vol. 18, No 1 Hal, 24-31

Barbara. Et. All. 2001. The Canfield Learning Styles Inventory: An Assesment of its Ussefulnes in Accountiong Education Research. Issues in Accounting Education fall. 16 no. 3. Agustus.

Canfield, A and W. Knight. 1983. Learning Style Inventory. Los Angeles. CA: Western Psycological Services

Franchis, M. C., T. Mulder and J. S Stark. 1995. International Learning: a Process of Learning to Learn in The Accounting Curriculum. Sarasota, FL: American Accounting Association.

Gaiger. 1992. Learning Style of Student and Instructor: an Analysis of Course Performance and Satisfaction. The Accounting Education Journal.

Hickocx, L. K. 1995. Learning styles: A survey of adult learning style inventory models.

In R. R. Sims \& S. J. Sims (Eds). The importance of learning styles: Understanding the implications for learning, course design, and education. Wesport, CT: Grenworod Press.

Kolb. D. A. 1985. Learning Style Inventory Self Scoring Inventory and Interpretation Buuklt. Boston, NA: MCBER and Company.

Phibin, M., Meier, E., Huffman, S., \& Bouverse, P. 1995. April. A Survey of gender and

learning styles. Sex Roles, 32, 484

Pujiningsih, Sri. 2006. Metode Pengajaran dan Gaya Belajar Dosen Akuntansi FE-UM, Laporan Penelitian Imbal Swadaya. 